\title{
INVESTMENT DECISION RULES IN A COMPETITIVE MARKET AND IN THE CASE OF CO-OPETITION. THE REAL OPTIONS GAMES APPROACH
}

The main goal and the original role of this paper were to find and describe decisional rules used by firms based on the net present value of an investment project and on the investment option value for different market conditions (competition or co-opetition). The investment decision-making process is described as a game between two players, while the real options analysis (ROA) is used to find the value of an investment project, thus the paper falls in the category of real options games (ROG). An analysis of these games may help explain some of the aspects of a firm's behaviour and offer some guidelines to managers. In a purely competitive environment, a firm will not delay execution of the project because of the risk of being outdistanced by competitors. In this case, firms will be interested in using the real option framework in their decision-making process only when the classic NPV is definitely negative, even if the real option theory recommends using it in some cases when NPV is positive. A co-opetition case offers much better prospects for the application of ROA. The introduction of cooperation arrangements among competitors reduces the area of conflict of interest between them. Firms that build a co-opetition relationship should be more interested in using the real options approach. Nevertheless, it should be emphasised that while the risk of the project is high, the creation of a co-opetition relationship requires much more attention and consideration due to the threat of contract termination. Nonetheless the benefits that firms enjoy by following a co-opetition agreement are more substantial only in the case of high-risk projects. An additional innovative contribution of the paper is taking into account the interactions between the model parameters. This is essential in performing a sensitivity analysis and it reflects the links observed in practical applications.

Keywords: Real options, investment option, competition, co-opetition, real options games, game theory

DOI: $10.15611 /$ aoe.2019.2.14

\section{INTRODUCTION}

In the face of the rapidly changing business environment, firms are forced to seek new winning strategies to gain advantage in the market and to create value for their owners. Co-opetition is one of the ways to create value they

\footnotetext{
* Institute of Informatics and Quantitative Economics, Poznań University of Economics and Business.
} 
can choose, while the real options approach is one of the valuation tools they have at hand.

Co-opetition in one of the four types of relationships that can develop among competitors depending on the nature of the interaction between firms. Bengtsson and Kock (1999) and Bengtsson, Hinttu and Kock (2003) argue based on Easton and Araujo (1992) - that these are: coexistence, cooperation, competition, and co-opetition.

1. Coexistence means that no bonds are present; firms do not interact with each other. There is no game between them.

2. In the case of cooperation, all types of links can be established. Firms have common goals. Firms' interdependence is based on a positive-sum game. It is a win-win situation: both parties profit from the situation.

3. Competition is the rivalry between the parties. Their interests are dissimilar and irreconcilable. The success and value appropriation by one firm means the defeat and the loss of value of other firms; inter-firm interdependence is based on a zero-sum game (Dagnino, Padula 2002, p. 7).

4. In a co-opetitive relationship, firms interact according to two different logics of interaction: cooperation and competition (Brandenburger, Nalebuff 1996). However, co-opetition is not merely about combining the aspects of competition and cooperation. It implies that cooperation and competition merge together to make a new kind of strategic interdependence between firms, resulting in a co-opetitive system of value creation (Dagnino, Padula 2002 , p. 4). Value creation, which requires combining the complementary resources and unique competences of both partners and sharing their values, is the hallmark of co-opetition. Firms' interdependence is based on a variable-positive-sum game (Dagino, Padula 2002, p. 13). It could even be a win-win-win situation, with the third beneficiary being the consumer (Walley 2007, p. 16).

Any firm's prerogative is to make investments to create value, thus it needs effective investment decision rules. A whole array of rules is commonly available to support the investment decision-making process. The most prevalent is the NPV rule. Notwithstanding its merits, the NPV rule has a lot of limitations, the most prominent being disregard for the aspects of managerial flexibility and strategic value. The NPV rule defines an investment decision as a "now or never" proposition. To capture the full value of an investment opportunity, economists use real options and incorporate a "wait-and-see" strategy into the decision-making process (Smit, Trigeorgis 2004). However, in the standard real options analysis (ROA), a firm formulates its investment decision in isolation, taking no 
notice of interactive competition. It has an exclusive exercise right, retaining all project benefits for itself. The investment opportunity is a proprietary option, the market is a monopolistic one. The investment decision: invest, delay (wait-and-see) or abandon a project, emerges from the comparison between the value of the investment option $\left(F_{0}\right)$, the net present value of the project $\left(N P V_{0}\right)$, and zero (Table 1).

Table 1

Investment rules in the case a monopoly (a proprietary option) in the Real Option Analysis

\begin{tabular}{c|c|c|c}
\hline Region & $\begin{array}{c}\text { The relationship between } \\
\text { the benefits of immediate } \\
\text { investment and the option value }\end{array}$ & Decision/strategy & Payment \\
\hline$I$ & $N P V_{0}<F_{0}, F_{0}=0$ & Abandon project & 0 \\
\hline$I I$ & $N P V_{0}<F_{0}, F_{0}>0$ & $\begin{array}{c}\text { Keep investment option } \\
\text { Delay investment project }\end{array}$ & $F_{0}$ \\
\hline & $0<F_{0}=N P V_{0}$ & $\begin{array}{c}\text { Keep investment option } \\
\text { or invest immediately }\end{array}$ & $F_{0}=N P V_{0}$ \\
\hline$I I I$ & $0<F_{0}<N P V_{0}$ & Invest immediately & $N P V_{0}$ \\
\hline
\end{tabular}

Source: own work based on Dixit, Pindyck (1994).

In practice, however, investments take place in a competitive environment. There are strategic interactions between firms implementing investments, and a new market opportunity is available to many of them. Thus the most real options are, in fact, shared options. A shared option means that two (or more) firms share the same investment opportunity. In this case, the presence of market competitors can significantly affect the real option value and the firm's optimal exercise strategy of investment option (Chevalier-Roignant, Trigeoris 2011, p. 35). Hence, we need investment rules valid also for firms functioning in the competitive market. Yet, to the best of the author's knowledge, no previous papers have formulated them (in terms of NPV and ROA).

Therefore the main goal and the unique contribution of this paper is to find and describe rules of investment decision followed by firms, based on the net present value of a project and the investment option value, depending on market conditions (competition or co-opetition). Investment decisionmaking has been described as a game between two players, while the real options approach is used to find the value of the investment project. Hence, this paper falls in the category of real options games (ROG) (Smit, Ankum 1993, Brandenburger, Nalebuff 1995, Grenadier 2000, Smit, Trigeorgis 2004, Chevalier-Roignant, Trigeoris 2011, Trigeorgis, Baldi 2013, Rychłowska- 
Musiał 2017b). We will examine the impact of risk (measured by volatility) on the firm's investment strategy in competitive and co-opetitive relationships. Furthermore, we will explain under what circumstances a company would be willing to cooperate with its competitor and use ROA, and when it would not.

The papers that are probably the closest to this one have been published by Trigeorgis and Baldi (2013) and Rychłowska-Musiał (2017a), however there are some important differences between them. Trigeorgis and Baldi (2013) consider the dynamic concept of strategy enabling the firm to alternate between compete, cooperate or wait modes; games between firms are played in the end-of-period nodes of the binominal trees; the payoffs are multiplied by the respective probabilities and discounted back at the riskless rate. By contrast, we consider a game at the initial moment and payoffs are constituted in this moment. Furthermore, for a common investment opportunity (a shared option), Trigeorgis and Baldi divide an option value between both parties. We assume that for a common investment opportunity in the competitive market only the project benefits (the "market pie") are shared between firms while expenditures are not. The major differences regarding all previous papers consist in the assumptions about the links between model parameters and the present value of the project. Having considered a wide range of project present values, we can formulate the requested investment rules and conduct their in-depth analysis.

The rest of the paper is structured as follows. Section 2 presents the basic assumptions for the model of interaction between firms and the links between its parameters. The next two sections explain two variants of the model, i.e. pure competition (Section 3) and co-opetition (Section 4). Section 5 analyses the benefits of co-opetition and Section 6 provides the conclusions.

\section{THE MODEL OF INTERACTION BETWEEN FIRMS - AN OPTION GAME}

Consider two identical risk-neutral firms (A and B) operating on a competitive market. A new investment opportunity arises for each of them. Both competitors share the same investment opportunity - it is a shared option. (Smit, Trigeorgis 2004, p. 35). Either of the firms may exercise the option by paying an investment expenditure $I, I>0$. We assume that the lifetime of the project is infinite. Firms can invest immediately, or defer an investment for time $T$, leaving the investment option pending until new information comes from the market. 
If the two firms invest at the same time, they share benefits from the market. Since the firms are identical, the distribution is equal. If one firm invests at the initial moment $t=0$, it seizes all the project benefits, while the firm deferring investment is left empty-handed.

Companies can operate in conditions of pure competition or can decide to cooperate in project financing, and consequently enjoy the benefits of the project in a competitive market, which means creating a co-opetition relationship.

The project generates cash flows $Y_{t}$, which evolve in accordance with the geometric Brownian motion, with drift $\alpha, \alpha>0$, and volatility $\sigma, \sigma>0$, under the risk-neutral measure. A risk-free asset yields a constant rate of return $r ; \delta$ is a convenience yield $(\delta>0)$ and it reflects an opportunity cost of delaying construction of the project whilst still retaining an option to invest (Dixit, Pindyck 1994, p. 149). The present value of the project is determined by the discounting and accumulating of its future cash flows. It is equal to $V_{0}=V\left(Y_{0}\right)=\frac{Y_{0}}{\delta}$ (Dixit, Pindyck 1994, p. 181).

We are going to discuss the influence of project risk on a firm's investment strategy through the real option value and the NPV. When risk parameter $\sigma$ varies, we must examine what happens to other parameters of the model. Dixit and Pindyck (1994, pp. 148-150, 178-179) propose using the Capital Asset Pricing Model (CAPM) to determine these links. Empirical evidence that the CAPM does a reasonable job in explaining (real) optionadjusted stock returns is provided e.g. by Da, Guo, and Jagannathan (2012).

Thus, let $\mu$ be the total expected rate of return from owning the completed project. It is the sum of the expected percentage rate of growth of $Y_{t}(\alpha)$ and the convenience yield $(\delta)$ :

$$
\mu=\alpha+\delta .
$$

On the other hand, let $\mu$ be the expected rate of return from holding a financial asset (non-dividend paying) perfectly correlated with $Y_{t}$. According to CAPM, it will be given by:

$$
\mu=r+\beta\left(r_{m}-r\right)
$$

where $r_{m}$ is the expected return in the market and coefficient $\beta$ indicates whether the asset is more $(\beta>1)$ or less $(0<\beta<1)$ volatile than the market.

Coefficient $\beta$ depends among others on $\sigma, \beta=\frac{\rho_{m} \sigma}{\sigma_{m}}$ (where $\rho_{m}$ is the 
correlation of the asset with the market portfolio and $\sigma_{m}$ is the standard deviation of $r_{m}$ ).

Under the assumption of constant risk-free rate $r$ and constant expected return in the market $r_{m}$, the most important links are between the project risk $\sigma$, the opportunity cost of delaying investment $\delta$, and the expected percentage rate of changes in cash flows $\alpha$. Dixit and Pindyck (1994) emphasise that these links may not be overt.

We will assume that $\alpha$ is a fundamental fact about $Y_{t}$ and that links exist only between $\sigma$ and $\delta$. According to:

$$
r+\frac{\rho_{m} \sigma}{\sigma_{m}}\left(r_{m}-r\right)=\alpha+\delta
$$

when $\sigma$ increases, $\delta$ is also higher.

When considering the project implementation, a firm can choose between two strategies: Wait or Invest (the third strategy: Abandon, when the investment option value equals zero, is also possible, but it will not be tackled in this paper). The primary criterion for taking investment decisions is the comparison between the investment option value and the benefits of instantaneous investment. However, for the shared option a firm must incorporate its rivals' decision into its decision-making process. A firm has to take account of the impact exerted by its investment decision on its competitor as well as of the impact exerted by the rival's reactions. Therefore, the strategic choices made by firms could be described as non-zero sum games.

\section{PURE COMPETITION}

Under pure competition conditions, firms' interests are diametrically divergent. There are four possible cases. The decision to invest or to defer is made at time $t=0$, therefore the functions of payments are as follows:

1. Firms $\mathrm{A}$ and $\mathrm{B}$ invest immediately and simultaneously. The simultaneous entry of both competitors into a market may result in a reduced total market value pie due to the ensuing price war. Then they share (equally) the (reduced) project benefits, and the payment for each firm is the net present value of the project considering the reduced project benefits:

$$
N P V_{0}^{D}:=\left.N P V\left(0.5 n Y_{t}\right)\right|_{t=0}=V\left(0.5 n Y_{0}\right)-I=0.5 n V_{0}-I \text {. }
$$

where: $n$-a multiplier of reducing the underlying market value $(0<n \leq 1)$. 
2. Firms A and B defer investments and keep an open investment option. In this case, the payment for each of them is the call option value determined in the Black-Scholes-Merton model. The underlying asset is the present value of the project determined with a half of the (reduced) project benefits $\left(0.5 n Y_{t}\right)$, and the exercise price is the investment expenditure $I$ :

$$
F_{0}^{D}:=\left.F\left(0.5 n Y_{t}\right)\right|_{t=0} .
$$

3. Firm A invests immediately and appropriates the whole market. Its payment is the net present value of the total project:

$$
N P V_{0}:=\left.N P V\left(Y_{t}\right)\right|_{t=0}=V\left(Y_{0}\right)-I=V_{0}-I,
$$

firm B defers investment decision and its payment is zero.

Table 2

\begin{tabular}{|c|c|c|c|}
\hline Parameter & Notation & Basic value & Proposed estimation procedure \\
\hline $\begin{array}{l}\text { Investment } \\
\text { expenditures }\end{array}$ & $I$ & 6 (monetary unit) & Expert calculations \\
\hline Expiration date & $T$ & 2 (years) & Maximal time to delay investment decision \\
\hline Risk free interest rate & $r$ & $1.96 \%{ }^{\mathrm{a}}$ & $\begin{array}{c}\text { The interest rate on treasury bonds with } \\
\text { maturity date equal to expiration date of } \\
\text { investment option }\end{array}$ \\
\hline $\begin{array}{l}\text { The expected } \\
\text { percentage rate of } \\
\text { change of project cash } \\
\text { flows }\end{array}$ & $\alpha$ & $1 \%$ & Expert prediction \\
\hline $\begin{array}{l}\text { Volatility of the } \\
\text { project cash flows and } \\
\text { a spanning asset }\end{array}$ & $\sigma$ & $\begin{array}{l}20 \% \text { (low risk) } \\
60 \% \text { (high risk) }\end{array}$ & $\begin{array}{l}\text { Calculated based on historical data of spanning } \\
\text { asset or expert prediction }\end{array}$ \\
\hline $\begin{array}{l}\text { The expected rate of } \\
\text { return in the market }\end{array}$ & $r_{m}$ & $6.03 \%{ }^{b}$ & $\begin{array}{l}\text { The rate of return on market index, i.e. WIG or } \\
\text { WIG } 20 \text { calculated based on historical data }\end{array}$ \\
\hline $\begin{array}{l}\text { The standard deviation } \\
\text { of } r_{m}\end{array}$ & $\sigma_{m}$ & $14.65 \%{ }^{\mathrm{b}}$ & $\begin{array}{l}\text { The standard deviation of the rate of return on } \\
\text { market index, i.e. WIG or WIG } 20\end{array}$ \\
\hline $\begin{array}{l}\text { The correlation of the } \\
\text { asset with the market } \\
\text { portfolio }\end{array}$ & $\rho_{m}$ & 0.5 & Expert calculations \\
\hline $\begin{array}{l}\text { The convenience yield } \\
\text { reflecting an } \\
\text { opportunity cost of } \\
\text { delaying the project }\end{array}$ & $\delta$ & $\begin{array}{l}3.74 \% \text { (low risk) } \\
9.29 \% \text { (high risk) }\end{array}$ & Formula; $\delta=r+\left(r_{m}-r\right) \cdot \beta-\alpha$ \\
\hline Coefficient $\beta$ & $\beta$ & $\begin{array}{l}0.68 \text { (low risk) } \\
2.05 \text { (high risk) }\end{array}$ & Formula; $\beta=\frac{\sigma \cdot \rho_{m}}{\sigma_{m}}$ \\
\hline
\end{tabular}

Key parameters of the model

Source: author's own; ${ }^{\text {a }}$ YTM of 2-year treasury bonds; ${ }^{b}$ WIG 2012-2016, data from stooq. 
4. Firm A defers investment decision and firm B invests right away. Then their payments are corresponding to the one in case 3 .

To visualise the values of these payments and to analyse the games, let us assume a basic set of parameters. The assumptions about the parameters reflect the situation of a real company (a similar approach is used by the authors of the cited papers). They are summarised in Table 2.

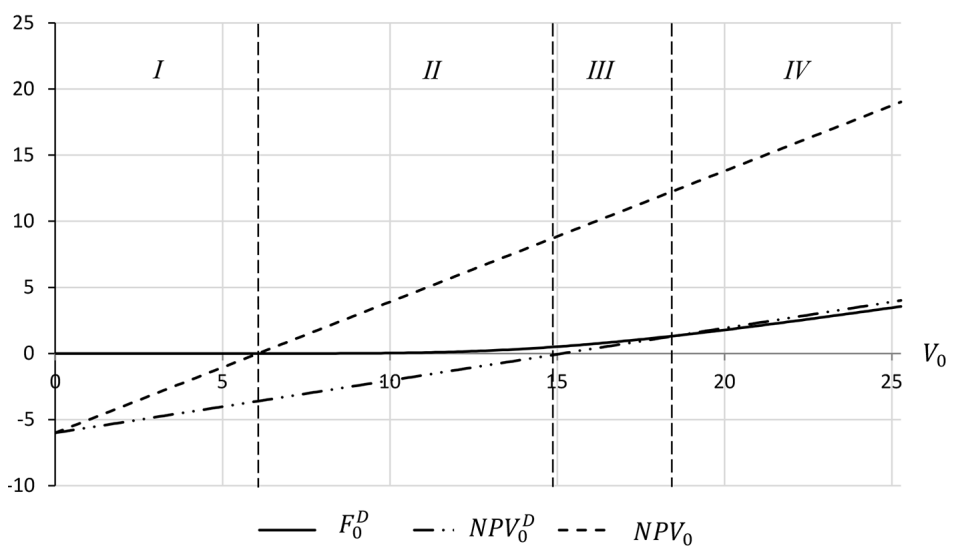

(a)

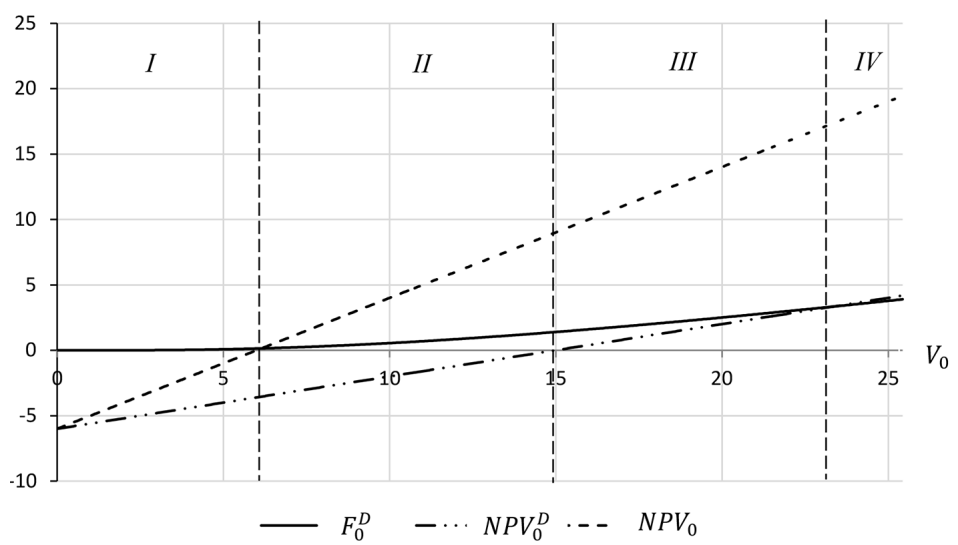

(b)

Fig. 1. The pure competition case: the investment option value $\left(F_{0}^{D}\right)$, the net present value for the only investor $\left(N P V_{0}\right)$ and the net present value when both firms invest immediately and simultaneously $\left(N P V_{0}^{D}\right)$ for different present values of the project $\left(V_{0}\right)$ and regions of firms' interactions. Base case parameters, (a) low risk; (b) high risk.

Source: author's own work. 
We formulate the games and define the strategies at time $t=0$ for different initial values of the cash flows generated by the project $Y_{0}>0$, and hence, for the different total present values of the project $V_{0}>0$. Additionally, we assume the multiplier of reducing the underlying market value in the case of price war $n=0.8$.

Figure 1 presents the option value $\left(F_{0}^{D}\right)$ and the benefits of instantaneous investment for the only investor $\left(N P V_{0}\right)$ and when the firms invest immediately and simultaneously $\left(N P V_{0}^{D}\right)$.

Analogously to ROA, also in the ROG concept the strategic decision (to wait or to invest) is determined by the relationship between the value of the investment option and the benefits of immediate investment. However, the move of a competitor must also be considered. If the investment decision is delayed, a firm can research the market better and wait for more accurate information. Yet in the competitive environment, such firm's behaviour could be risky. If an investment opportunity is a shared option, delaying the investment decision may reduce the option value for the rival's decision of instantaneous investment. Therefore in a competitive environment, the investment strategy appears to be the outcome of an option game between firms. Table 3 presents the normal form of this game.

Table 3

Payoff matrix in a competitive environment

FIRM B

\begin{tabular}{|c|c|c|c|}
\hline \multirow{3}{*}{ FIRM A } & & $W A I T(W)$ & $\operatorname{INVEST}(I)$ \\
\hline & $W A I T(W)$ & $\left(F_{0}^{D} ; F_{0}^{D}\right)$ & $\left(0 ; N P V_{0}\right)$ \\
\hline & $\operatorname{INVEST}(I)$ & $\left(N P V_{0} ; 0\right)$ & $\left(N P V_{0}^{D} ; N P V_{0}^{D}\right)$ \\
\hline
\end{tabular}

Source: own study.

The type of game, the way it is played and the payments, are contingent on the relationship between the values: $N P V_{0}, N P V_{0}^{D}, F_{0}^{D}$, and 0 . Depending on these values, four ranges of the present value of the project benefits $\left(V_{0}\right)$ appear. In each region, firms play different games.

We are going to determine a dominant strategy for each player in each game (if it exists), and indicate the Nash equilibrium (NE). In the NE, no player has anything to gain by changing only its own strategy. If the other player is rational, it is reasonable for each of them to expect the opponent to follow the recommendation of NE as well (Watson, 2013, p.82). Therefore, 
the Nash equilibrium is a kind of prediction of how the game will be played by rational players.

In region $I$ the net present value of the project is very low, it is lower than the investment option value: $N P V_{0}<F_{0}^{D}$ and $F_{0}^{D}>0$. Sample payoffs in the game for this region are presented in Table 4.

Table 4

Example of payoff matrix for region $I\left(V_{0}=5\right)$; low risk (a) or high risk (b)

\begin{tabular}{c|c|c|}
\multicolumn{1}{c}{} & \multicolumn{1}{c}{$\operatorname{WAIT}(W)$} & \multicolumn{1}{c}{$\operatorname{INVEST}(I)$} \\
\cline { 2 - 3 } $\operatorname{WAIT}(W)$ & $(0.001 ; 0.001)$ & $(0 ;-1)$ \\
\cline { 2 - 3 } $\operatorname{INVEST}(I)$ & $(-1 ; 0)$ & $(-4 ;-4)$ \\
\cline { 2 - 3 } & \multicolumn{2}{l}{}
\end{tabular}

(a)

\begin{tabular}{c|c|c|}
\multicolumn{1}{c}{} & \multicolumn{1}{c}{$\operatorname{WAIT}(W)$} & \multicolumn{1}{c}{$\operatorname{INVEST}(I)$} \\
\cline { 2 - 3 } $\operatorname{WAIT}(W)$ & $(0.08 ; 0,08)$ & $(0 ;-1)$ \\
\cline { 2 - 3 } $\operatorname{INVESTT}(I)$ & $(-1 ; 0)$ & $(-4 ;-4)$ \\
\hline
\end{tabular}

(b)

Source: author's own work.

The dominant strategy is Wait: keep the investment option open. Since a strictly dominant strategy exists for each player in the game, the game has only one unique Nash equilibrium $(W ; W)$. This strategy profile yields the highest payments for both players $\left(F_{0}^{D} ; F_{0}^{D}\right)$. In this region, when the benefits of the project are low, waiting is the optimal decision.

The situation changes completely when the net present value of the project for the only investor exceeds the value of the investment option, but at the same time the net present value of the project when both firms invest, remains negative: $N P V_{0}^{D}<0<F_{0}^{D} \leq N P V_{0}$, region $I I$. This means that if the company is the only investor in the market, it reaps the benefits. If both firms invest at the same time, they suffer losses - the market does not provide revenues sufficient to cover expenditures for both of them. However, players can risk the implementation of the project despite the existing threat. Sample payoffs in the game for this region are presented in Table 5 .

Table 5

Example of payoff matrix for region $I I\left(V_{0}=10\right)$; low risk (a) or high risk (b)

\begin{tabular}{c|c|c|}
\multicolumn{1}{c}{} & \multicolumn{1}{c}{$\operatorname{WAIT}(W)$} & \multicolumn{1}{c}{$\operatorname{INVEST}(I)$} \\
\cline { 2 - 3 } $\operatorname{WAIT}(W)$ & $(0.03 ; 0.03)$ & $(0 ; 4)$ \\
\cline { 2 - 3 } $\operatorname{INVEST}(I)$ & $(4 ; 0)$ & $(-2 ;-2)$ \\
\cline { 2 - 3 } & & \multicolumn{2}{|c}{$(\mathrm{a})$}
\end{tabular}

(a)

\begin{tabular}{|c|c|}
\multicolumn{1}{|c|}{$\operatorname{WAIT}(W)$} & \multicolumn{1}{c}{$\operatorname{INVEST}(I)$} \\
\hline$(0.55 ; 0.55)$ & $(0 ; 4)$ \\
\hline$(4 ; 0)$ & $(-2 ;-2)$ \\
\hline
\end{tabular}

(b)
Source: author's own work.

$\operatorname{WAIT}(W)$ $\operatorname{INVEST}(I)$ 
This game has two pure non-equivalent and non-interchangeable equilibria: $(W ; I)$ and $(I ; W)$; there is also a mixed strategy equilibrium wherein each player Waits with probability $p(p W,(1-p) I ; p W,(1-p) I)$. This is the most difficult situation for both players, and the benefits are hardest to achieve. This game has no dominant strategy for any player. Each of them may seek a different equilibrium by making the decision Invest - the worst possible, and by giving the lowest possible payments to both players $(I ; I)$. Note that both could achieve better results at the strategy profile $(W ; W)$.

A slightly improved, but still suboptimal situation, is in region $I I I$ : $0<N P V_{0}^{D}<F_{0}^{D}<N P V_{0}$. The game in this region is the prisoner's dilemma. This game has only one dominant strategy (Invest) and only one Nash equilibrium - strategy profile $(I ; I)$. In this case, the simultaneous investment does not lead to losses ( $N P V_{0}^{D}$ is slightly above zero), but even so, both companies would benefit from waiting, keeping the investment option open and by observing the market. The payoff amounts in the strategy profile $(W ; W)$ are higher than in profile $(I ; I)$. Sample payoffs in the game for this region are presented in Table 6.

Table 6

Example of payoff matrix for region $I I I\left(V_{0}=16\right)$; low risk (a) or high risk (b)

\begin{tabular}{c|c|c|}
\multicolumn{1}{c}{} & \multicolumn{1}{c}{$\operatorname{WAIT}(W)$} & \multicolumn{1}{c}{$\operatorname{INVEST}(I)$} \\
\cline { 2 - 3 } $\operatorname{WAIT}(W)$ & $(0.76 ; 0.76)$ & $(0 ; 10)$ \\
\cline { 2 - 3 } $\operatorname{INVEST}(I)$ & $(10 ; 0)$ & $(0.4 ; 0,4)$ \\
\cline { 2 - 3 } & &
\end{tabular}

(a)

\begin{tabular}{c|c|c|}
\multicolumn{1}{c}{} & \multicolumn{1}{c}{$\operatorname{WAIT}(W)$} & \multicolumn{1}{c}{$\operatorname{INVEST}(I)$} \\
\cline { 2 - 3 } $\operatorname{WAIT}(W)$ & $(1.61 ; 1.61)$ & $(0 ; 10)$ \\
\cline { 2 - 3 } $\operatorname{INVEST}(I)$ & $(10 ; 0)$ & $(0,4 ; 0,4)$ \\
\cline { 2 - 3 } & &
\end{tabular}

(b)

Source: author's own work.

When the net present value of the project for both companies exceeds the value of the investment option $\left(0<F_{0}^{D}<N P V_{0}^{D}\right.$, region $\left.I V\right)$, the optimal strategy for both players becomes the strategy profile $(I ; I)$. It is the dominant strategy leading to Nash equilibrium, and the payoffs in this strategy profile are the highest for both players. For high values in the project, Invest is the best natural decision. Sample payoffs in the game for this region are presented in Table 7. 
Table 7

Example of payoff matrix for region $I V\left(V_{0}=25\right)$; low risk (a) or high risk (b)

\begin{tabular}{c|c|c|}
\multicolumn{1}{c}{} & \multicolumn{1}{c}{$\operatorname{WAIT}(W)$} & \multicolumn{1}{c}{$\operatorname{INVEST}(I)$} \\
\cline { 2 - 3 } $\operatorname{WAIT}(W)$ & $(3.55 ; 3.55)$ & $(0 ; 19)$ \\
\cline { 2 - 3 } $\operatorname{INVEST}(I)$ & $(19 ; 0)$ & $(4 ; 4)$ \\
\cline { 2 - 3 } & &
\end{tabular}

(a)

\begin{tabular}{c|c|c|}
\multicolumn{1}{c}{} & \multicolumn{1}{c}{$\operatorname{WAIT}(W)$} & \multicolumn{1}{c}{$\operatorname{INVEST}(I)$} \\
\cline { 2 - 3 } $\operatorname{WAIT}(W)$ & $(3.78 ; 3.78)$ & $(0 ; 19)$ \\
\cline { 2 - 3 } $\operatorname{INVEST}(I)$ & $(19 ; 0)$ & $(4 ; 4)$ \\
\cline { 2 - 3 } & &
\end{tabular}

(b)

Source: author's own work.

Table 8 summarises all the possible investment decision rules for firms on the competitive market categorised on the basis of project benefits, and consequently also on the basis of the real option value and the NPV of the project. NE strategies are the policies that will most likely be chosen by rational players, but NE does not have to provide them with the highest available payoffs.

Table 8

Investment decision rules in a competitive market (a shared option) in the Real Options Games Approach

\begin{tabular}{|c|c|c|c|c|c|}
\hline \multirow{2}{*}{ Region } & \multirow{2}{*}{$\begin{array}{l}\text { The relationship } \\
\text { between the benefits } \\
\text { of immediate investment } \\
\text { and the option value }\end{array}$} & \multicolumn{2}{|c|}{ Nash Equilibrium } & \multicolumn{2}{|c|}{$\begin{array}{l}\text { The highest payoff } \\
\text { simultaneously } \\
\text { for BOTH players }\end{array}$} \\
\hline & & $\begin{array}{c}\text { Strategy } \\
\text { profile }\end{array}$ & Payment & $\begin{array}{c}\text { Strategy } \\
\text { profile }\end{array}$ & Payment \\
\hline$I$ & $\begin{array}{c}N P V_{0}^{D}<N P V_{0}<F_{0}^{D} \\
F_{0}^{D}>0\end{array}$ & $(W ; W)$ & $\left(F_{0}^{D} ; F_{0}^{D}\right)$ & $(W ; W)$ & $\left(F_{0}^{D} ; F_{0}^{D}\right)$ \\
\hline II & $N P V_{0}^{D}<0<F_{0}^{D}<N P V_{0}$ & $\begin{array}{c}(W ; I) \\
(I ; W) \\
(p W,(1-p) I \\
p W,(1-p) I)\end{array}$ & $\begin{array}{c}\left(0 ; N P V_{0}\right) \\
\left(N P V_{0} ; 0\right) \\
\left(p F_{0}^{D} ; p F_{0}^{D}\right)\end{array}$ & $(W ; W)$ & $\left(F_{0}^{D} ; F_{0}^{D}\right)$ \\
\hline III & $0<N P V_{0}^{D}<F_{0}^{D}<N P V_{0}$ & $(I ; I)$ & $\left(N P V_{0}^{D} ; N P V_{0}^{D}\right)$ & $(W ; W)$ & $\left(F_{0}^{D} ; F_{0}^{D}\right)$ \\
\hline$I V$ & $0<F_{0}^{D}<N P V_{0}^{D}<N P V_{0}$ & $(I ; I)$ & $\left(N P V_{0}^{D} ; N P V_{0}^{D}\right)$ & $(I ; I)$ & $\left(N P V_{0}^{D} ; N P\right.$ \\
\hline
\end{tabular}

Source: author's own work.

By analysing Tables 4 to 7 , we can notice that the higher the project risk, the greater the difference between the Nash equilibrium strategy payoff and the payoff in the strategy profile that gives the two players the highest 
payments possible. Furthermore, the higher the project risk, the larger the $I I$ and III ranges of present project values $V_{0}$ (Figure 2). In their case, the following types of games between competitors exist: a game without a dominant strategy (range $I I$ ) or the prisoner's dilemma (range $I I I$ ). If we assume the Nash equilibrium is a kind of prediction of a game solution applicable to rational players, ranges $I I$ and $I I I$ are the most difficult for players with respect to finding a satisfactory solution.

Consequently in the case of high-risk projects, the lack of cooperation in the decisions taken by the firms leading to non-optimal payments poses a much greater threat noticeable in a wider range of project values than for the lower-risk projects.

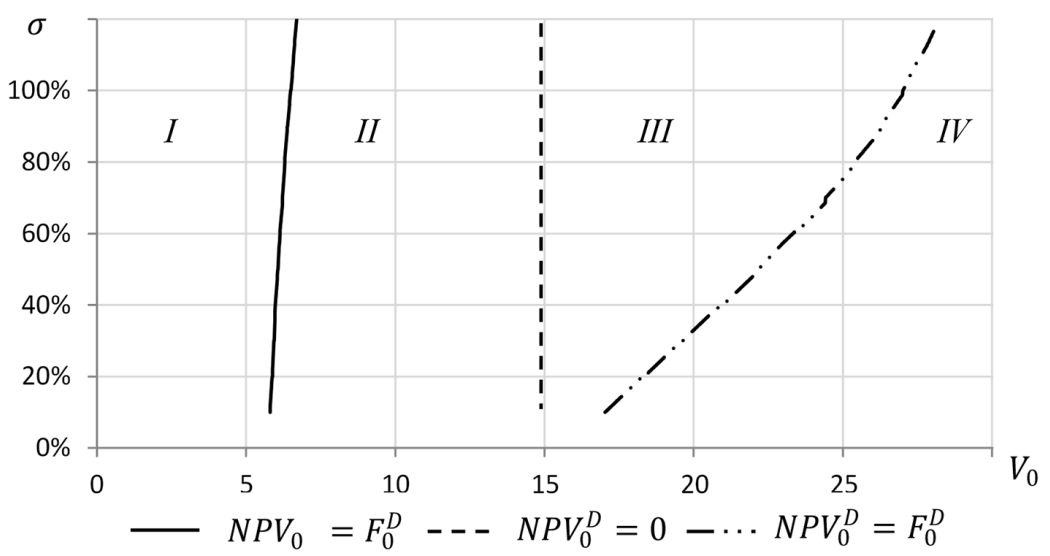

Fig. 2. The pure competition case: dependence of ranges of present project values $V_{0}$ (connected with the type of a game) on the project risk $\sigma$.

Source: author's own work.

Moreover, it is easy to demonstrate that the intensity of price wars influences the ranges of present project values in the same way. Hence, our findings seem to indicate that if we could develop a device for inducing players to act in the name of group rationality, the firm would achieve greater benefits than in the case of isolated, uncoordinated individual actions.

Note also that our considerations constitute a strong basis to formulate conclusions about possible managers' interest in using the Real Option Analysis in the decision-making process. In a purely competitive environment, the ROA will only be applicable when the classic NPV is distinctly negative, even if the real option theory recommends its use at positive NPV values. 


\section{CO-OPETITION}

A co-opetition arrangement between two firms may involve the adoption of a concerted strategy (Wait or Invest), however either of the parties will eventually make autonomous decisions and might reject the conditions of the cooperation agreement. This is because both firms are competitors in the market. We will assume that through a co-opetition agreement, firms can share investment expenditures and increase their economic profits through enlarging the size of the business pie, i.e. the underlying market value is increased by a multiplier (Ritala 2012, p. 309). There are five cases under co-opetition and the functions of payoffs (at time $t=0$ ) are as follows:

1. Firms A and B invest immediately and simultaneously. There is a coopetition arrangement between them; they share (in equal parts) project expenditures and benefits, whereas the underlying market value is increased by a multiplier $m$. The payment for each firm is the net present value of the project taking into account these enlarged and (equally) divided benefits and reduced expenditures of the project:

$$
N P V_{0}^{\text {coop }}:=\left.N P V\left(0.5 m Y_{t}\right)\right|_{t=0}=V\left(0.5 m Y_{0}\right)-0.5 I=0.5 m V_{0}-0.5 I,
$$

where $m$ - a multiplier, which increased the underlying market value $(m \geq 1)$.

2. Firms $\mathrm{A}$ and $\mathrm{B}$ maintain the co-opetition agreement, defer the investment and keep the investment option open. In this case, the payment for each of them is the call option value determined in the Black-ScholesMerton model, i.e. the underlying asset is the present value of the project determined with the use of half of the (enlarged) project benefits $\left(0.5 m Y_{t}\right)$, and the exercise price is half of the investment expenditure $(0.5 I)$ :

$$
F_{0}^{\text {coop }}:=\left.F\left(0.5 m Y_{t}\right)\right|_{t=0} .
$$

3. There is a co-opetition arrangement between firms, but firm A breaks the agreement and invests immediately. Therefore, it appropriates the whole market and bears all the investment expenditure, and consequently its payment is the net present value of the total project:

$$
N P V_{0}:=\left.N P V\left(Y_{t}\right)\right|_{t=0}=V\left(Y_{0}\right)-I=V_{0}-I,
$$

firm B defers the investment and its payment is zero. 
4. Firm A defers the investment while firm B breaches the co-opetition agreement and invests immediately. Then their payments are corresponding to those in case 3 .

5. There is a co-opetition arrangement between firms, but both of them breach it and invest immediately. In this scenario there are no benefits of cooperation, but a price war could ensue that would reduce the market value of project benefits. Thus for both entities the payments are:

$$
N P V_{0}^{D}:=\left.N P V\left(0.5 n Y_{t}\right)\right|_{t=0}=V\left(0.5 n Y_{0}\right)-I=0.5 n V_{0}-I,
$$

where: $n-$ a multiplier with which the underlying market value is reduced $(0<n \leq 1)$.

In Section 3, a basic set of parameters is established. Moreover, we assume the multiplier to increase the underlying market value $m=1.2$ (market value pie enlarged by 20\%). Figure 3 shows the values of all possible payoffs.

When both firms invest immediately within the framework of co-opetition, and when there is no problem with keeping the agreement, their payments are equal to $N P V_{0}^{\text {coop }}$. The result is there is no game between them. A market game emerges when both parties negotiate a co-opetition agreement to defer the execution of the project and to retain an investment option. However, subsequent to this agreement, they can make different decisions and adapt various investment strategies. Table 9 presents the normal form of this game.

The readers should note that the payoff matrix in the co-opetition case is very similar to the one that was observed in the pure competition case. The difference between them appears in the upper-left box if both firms decide to wait and keep the investment option, which results in respective payoffs $\left(F_{0}^{\text {coop }} ; F_{0}^{\text {coop }}\right)$; on the other hand, in the pure competition case, they were $\left(F_{0}^{D} ; F_{0}^{D}\right)$. As in the previous case, there are four ranges of the present value of project benefits $\left(V_{0}\right)$. In each region, firms play different games, and the types of these games and their Nash equilibria are determined as previously. Therefore, we can formulate the set of investment rules for firms applying to the co-opetition case when the Real Options Games approach is adopted (summarised in Table 10). As in the previous case, NE indicates strategies that will most likely be chosen by rational players, but the equilibrium will not necessarily give players the highest available payoffs. 


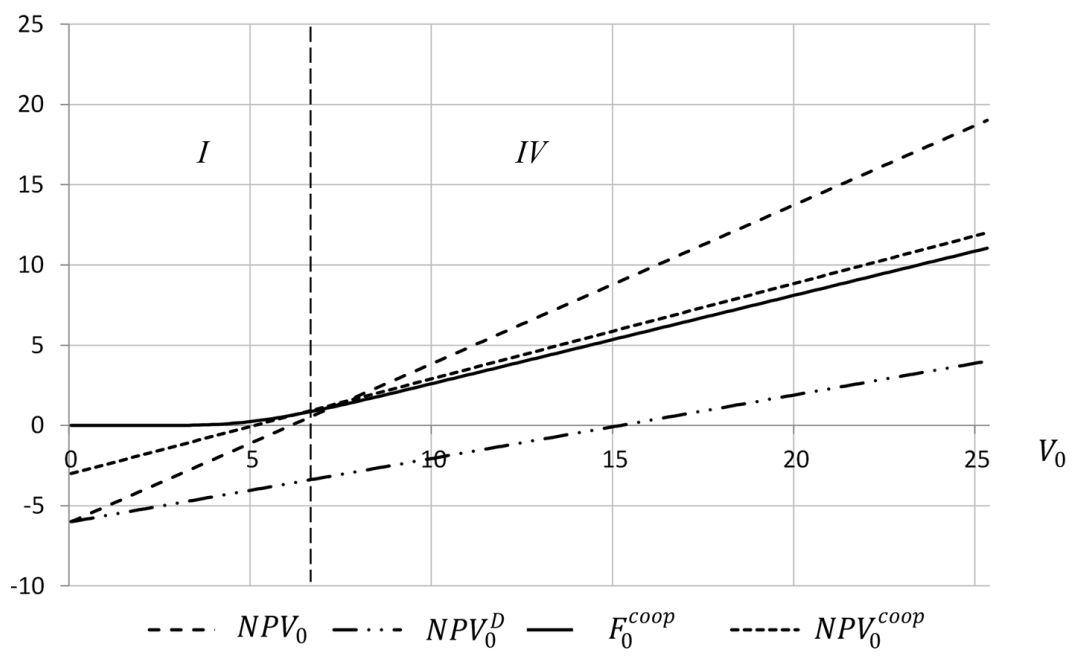

(a)

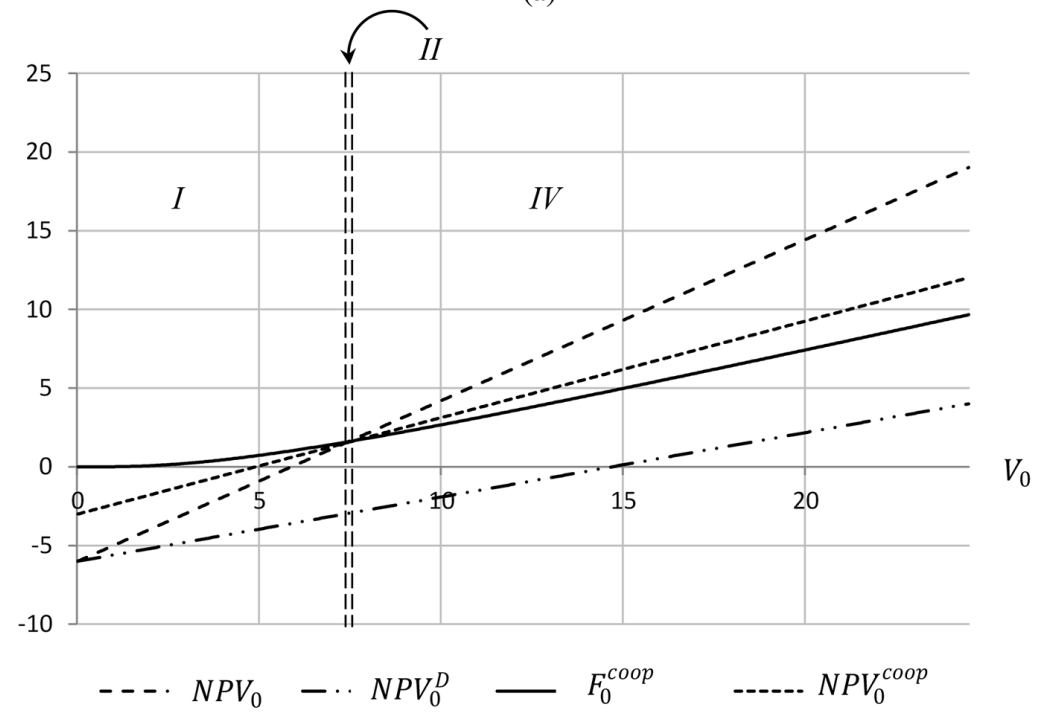

(b)

Fig. 3. The co-opetition case: the investment option value $\left(F_{0}^{c o o p}\right)$, the net present value for the only investor $\left(N P V_{0}\right)$ and the net present value when both firms invest immediately and simultaneously with benefits of cooperation $\left(N P V_{0}^{\text {coop }}\right)$ or without them $\left(N P V_{0}^{D}\right)$ for different present values of the project $\left(V_{0}\right)$ and regions of firms' interactions. Base case parameters, (a) low risk; (b) high risk.

Source: own study. 
Table 9

Payoff matrix in a co-opetition case

\begin{tabular}{|c|c|c|c|}
\hline & & & \\
\hline & & $W A I T(W)$ & $\operatorname{INVEST}(I)$ \\
\hline FIRM A & $W A I T(W)$ & $\left(F_{0}^{c o o p} ; F_{0}^{c o o p}\right)$ & $\left(0 ; N P V_{0}\right)$ \\
\hline & INVEST (I) & $\left(N P V_{0} ; 0\right)$ & $\left(N P V_{0}^{D} ; N P V_{0}^{D}\right)$ \\
\hline
\end{tabular}

Source: author's own work.

Table 10

Investment rules in a co-opetition case (a shared option) in the Real Option Games approach

\begin{tabular}{|c|c|c|c|c|c|}
\hline \multirow{2}{*}{ Region } & \multirow{2}{*}{$\begin{array}{c}\text { The relationship } \\
\text { between the benefits } \\
\text { of immediate inv } \\
\text { estment } \\
\text { and the option value }\end{array}$} & \multicolumn{2}{|c|}{ Nash Equilibrium } & \multicolumn{2}{|c|}{$\begin{array}{l}\text { The highest payoff } \\
\text { simultaneously } \\
\text { for BOTH players }\end{array}$} \\
\hline & & $\begin{array}{l}\text { Strategy } \\
\text { profile }\end{array}$ & Payment & $\begin{array}{l}\text { Strategy } \\
\text { profile }\end{array}$ & Payment \\
\hline$I$ & $\begin{array}{l}N P V_{0}<F_{0}^{\text {coop }} \\
\text { and } F_{0}^{\text {coop }}>0\end{array}$ & $(W ; W)$ & $\left(F_{0}^{c o o p} ; F_{0}^{c o o p}\right)$ & $(W ; W)$ & $\left(F_{0}^{c o o p} ; F_{0}^{c o o p}\right)$ \\
\hline II & $N P V_{0}^{D}<0<F_{0}^{c o o p} \leq N P V_{0}$ & $\begin{array}{c}(W ; I) \\
(I ; W) \\
(p W,(1-p) I ; \\
p W,(1-p) I)\end{array}$ & $\begin{array}{c}\left(0 ; N P V_{0}\right) \\
\left(N P V_{0} ; 0\right) \\
\left(p F_{0}^{c o o p} ;\right. \\
\left.p F_{0}^{c o o p}\right)\end{array}$ & $(W ; W)$ & $\left(F_{0}^{c o o p} ; F_{0}^{c o o p}\right)$ \\
\hline III & $\begin{array}{l}0<N P V_{0}^{D}<N P V_{0}^{\text {coop }} \leq \\
F_{0}^{\text {coop }}<N P V_{0}\end{array}$ & $(I ; I)$ & $\left(N P V_{0}^{D} ; N P V_{0}^{D}\right)$ & $(W ; W)$ & $\left(F_{0}^{c o o p} ; F_{0}^{c o o p}\right)$ \\
\hline$I V$ & $0<F_{0}^{c o o p}<N P V_{0}^{c o o p}$ & \multicolumn{4}{|c|}{$\begin{array}{l}\text { Immediate investment in the framework of the cooperation } \\
\text { agreement; payment for each party is } N P V_{0}^{\text {coop }}\end{array}$} \\
\hline
\end{tabular}

Source: author's own work.

\section{BENEFITS OF CO-OPETITION}

\subsection{Co-opetition vs. competition}

For $N P V_{0}^{\text {coop }}>N P V_{0}^{D}$ and $F_{0}^{\text {coop }}>F_{0}^{D}$, the differences between the payments when the co-opetition agreement is formulated and kept and the payments obtained under pure competition conditions are (almost) always 
positive. The problem of determining this difference can be seen in region $I I$, where it is difficult to predict how a game will be played and what its outcome will be (there is no dominant strategy). Furthermore, one can calculate that these benefits are greater when the project risk is higher. This means that under high risk circumstances, firms should be more interested in establishing a co-opetition relationship in order to stabilize the benefits and create a greater value from the project.

\subsection{Co-opetition - loyalty vs. disloyalty}

First of all, it is important to note that for very low present values of the project $V_{0}$ (when $N P V_{0}<F_{0}^{\text {coop }}$, region $I$ ), as well as for relatively high values (when $N P V_{0}^{\text {coop }}>F_{0}^{\text {coop }}$, region $I V$ ), there is no threat of breaching the co-opetition agreement. When $V_{0}$ is low, both firms defer the investment decision; when $V_{0}$ is high, both of them invest immediately and enjoy the benefits of cooperation. The threat of breaching the co-opetition agreement exists when the present value of the project benefits $\left(V_{0}\right)$ can be assigned to regions $I I$ or $I I I$. There is no dominant strategy in region $I I$ and players striving to achieve the best possible individual result can cause a situation when both of them lose (receive the worst possible payments). In region III the dominant strategy exists (breach of the contract) and leads to lower payments than in the case of observing the co-opetition agreement.

Let us note that when the project risk is low $(\sigma<60 \%$ for the base case parameters), there is no threat of a breach of the co-opetition agreement, irrespective of the present value of the project (Figure 4). This means that when the co-opetition benefits are substantial and when the project risk is not very high, firms could build a co-opetition relationship without the threat of being deceived. However, when the risk of the project is high, then ranges emerge wherein a conflict of interest between players exists (regions $I I$ and $I I I$ ) and there is the threat of a breach of the agreement (Figure 4). This is a consequence and the result of the types of the games the players become engaged in.

An influence of the reduction of co-opetition benefits (the smaller the enlargement of the market - the smaller the $m$ value, less than a $50 \%$ reduction of the project expenditure) is of the same nature. We can observe the conflict of interest between firms for the wider range of project benefits $V_{0}$ (Figure 5). 


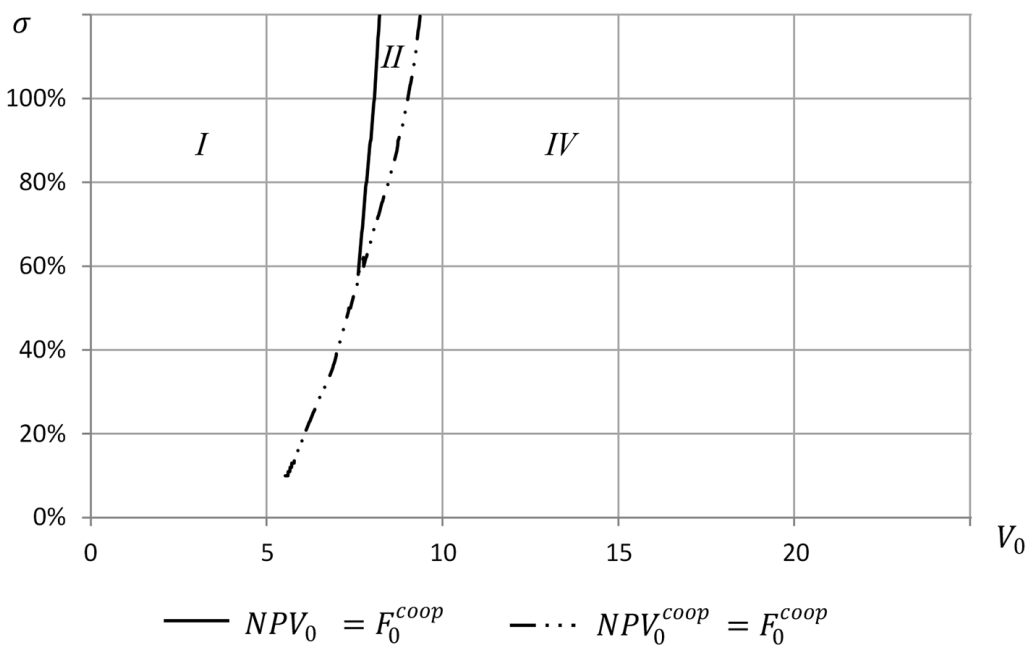

Fig. 4. The base case of co-opetition: dependence of ranges of present project values $V_{0}$ (connected with the type of a game) on the project risk $\sigma$. Base case of parameters.

Source: own study.

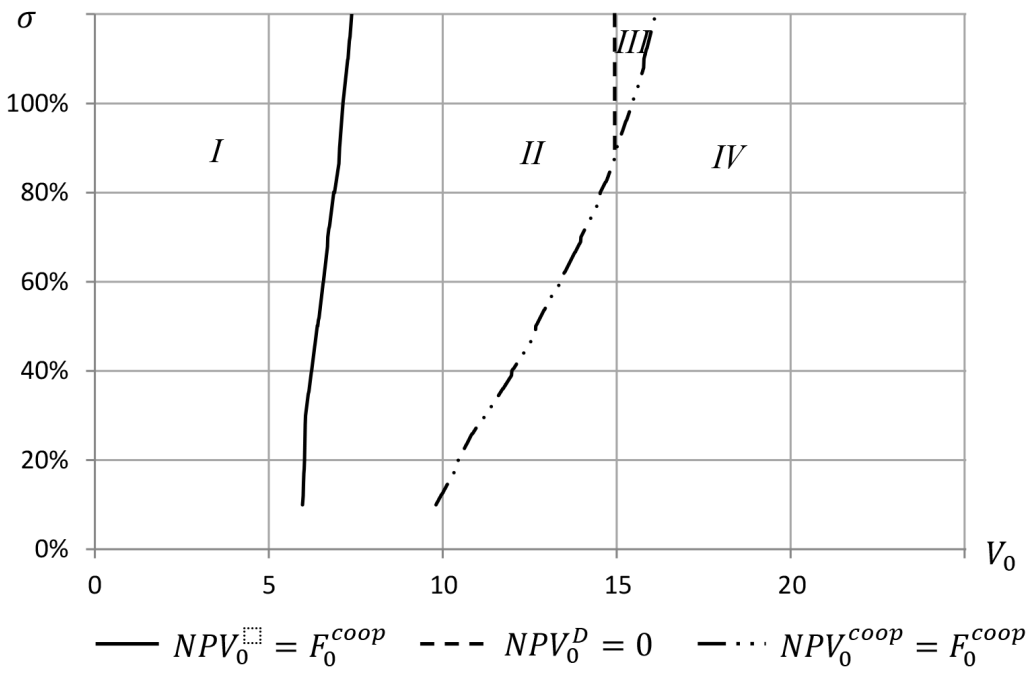

Fig. 5. The case of weaker co-opetition: dependence of ranges of present project values $V_{0}$ (connected with the type of a game) on the project risk $\sigma, m=1.05$ : a market value pie increased by $5 \%$, and an investment expenditure for both is $0.75 I$.

Source: own study. 
Conclusion: when projects are exposed to a greater risk or when their benefits are not so substantial, firms have to pay much more attention and give stronger consideration to creating a co-opetition relationship.

We can also calculate the benefits of following an agreement (the difference between the payment in the pessimistic scenario, where both firms breach the contract and invest independently, and the payment in the optimistic scenario where both sides adhere to the agreement and hold the investment option. It appears that the higher the project risk, the larger the benefits in these problematic ranges, which could mean that riskier projects should provide a greater incentive for firms to keep their co-opetition agreement.

\section{CONCLUSIONS}

An important part of a corporate strategy is to know when and how an investment project should be implemented. A firm must decide how to incorporate its rivals' policies into its own investment decision-making process. It must be able to recognise when it is a good time to coordinate strategies with its competitor to build a co-opetition relationship and when not to do so. This paper has discussed the rules applying to investment decisions on a competitive market as well as in a co-opetition case involving real options and games theory. The arguments elaborated on in the paper lead to some key findings:

1. In a purely competitive environment, the Real Option Analysis (ROA) will only be applicable when the classic NPV is definitely negative, even if the real option theory recommends its use in some cases of positive NPV. This may be one of the reasons why despite the initial enthusiasm, ROA has proven difficult to put into practice and why its implementation tends to be slow.

2. Therefore, the higher the project risk, the wider the range of the present value of the project in which the conflict of interest between competitors' influences the decision-making process.

3. Firms that create a co-opetition relationship have a greater capability to use ROA. A growing importance of co-opetition relationships and their dynamic development are a source of hope that the significance of ROA in the strategic decision-making process will increase.

4. A co-opetition relationship is easy to build and keep for low-risk projects, but for high-risk projects it requires much more attention and consideration. However, maintaining a co-opetition agreement provides greater benefits to firms where the project risk is higher. This means that high- 
risk projects should be a greater incentive for firms to adhere to their coopetition agreements and to receive more significant benefits.

Our results are based on an analysis conducted with the use of the European-style option pricing model by Black-Scholes-Merton. If the investment project is an American-style option, it will slightly affect the form of decision-making rules (in particular, regarding the American-style option, condition $F_{0}<N P V_{0}$ is never met); however, this will not affect the essence of the conclusions.

The results could shed some light on firms' market behaviour. However, some of our findings should also help managers understand how various externalities influence decision-making and value creation processes in a firm.

\section{REFERENCES}

Bengtsson, M., Kock S., Cooperation and competition in relationships between competitors in business networks, "Journal of Business and Industrial Marketing" 14 (3), 1999.

Bengtsson, M., Hinttu, S., Kock, S., Relationship of cooperation and competition between competitors. Work-in-Progress. Paper submitted to the 19th Annual IMP Conference, 4-6 Sept 2003, Lugano, 2003.

Brandenburger, A. M., Nalebuff, B. J., The right game: Use game theory to shape strategy, "Harvard Business Review" 73 (4), 1995.

Brandenburger, A. M., Nalebuff, B. J., Co-opetition. Doubleday, New York 1996.

Chevalier-Roignant, B., Trigeoris, L., Competitive strategy: Options and games. The MIT Press, 2011.

$\mathrm{Da}, \mathrm{Z}$., Guo, R., Jagannathan, R., CAPM for estimating the cost of equity capital: interpreting the empirical evidence, "Journal of Financial Economics", Vol. 103, pp. 204-220, 2012.

Dagnino, G. B., Padula, G., Coopetition strategy. A new kind of interfirm dynamics for value creation, Second Annual Conference "Innovative Research in Management", Stockholm, 9-11 May 2002.

Dixit, A. K., Pindyck, R. S., Investment under uncertainty. Princeton University Press, Princeton, New Jersey, 1994.

Easton, G., Araujo, L., Non-economic exchange in industrial networks, [in:] Axelsson, B., Easton, G. (eds.), Industrial networks - a new view of reality. Routledge, London 1992.

Grenadier, S. R., Game Choices: The intersection of real options and game theory. Risk Books, London 2000.

Ritala, P., Competition strategy - when is it successful? Empirical evidence on innovation and market performance, "British Journal of Management" Vol. 23, pp. 307-324, 2012.

Rychłowska-Musiał, E., Value creation in a firm through coopetition. Real options games approach, [in:] Jajuga, K., Orlowski, L. T., Staehr, K. (eds.), Contemporary Trends and Challenges in Finance, Proceedings from the 2nd Wroclaw International Conference on Finance, Springer Proceedings in Business and Economics, pp. 285-295, $2017 \mathrm{a}$. 
Rychłowska-Musiał, E., Opcje realne na rynku konkurencyjnym - gry opcyjnie [Real options in the competitive market - options' games], "Ekonomista” No. 4, pp.400-414, $2017 \mathrm{~b}$.

Smit, H. T. J., Ankum, L. A., A real options and game-theoretic approach to corporate investment strategy under competition, "Financial Management", Vol. 22, No. 3, pp. 241-250, 1993.

Smit, H. T. J., Trigeorgis, L., Strategic investment. Real options and games. Princeton University Press, Princeton and Oxford 2004.

Trigeorgis, L., Baldi, F., Patent strategies: Fight or cooperate?, Real Options Annual Conference, Tokyo, 25-26 June 2013.

Walley, K., Competition. An introduction to the subject and an agenda for research, "International Studies of Management and Organization" 37 (2), pp. 11-31, 2007.

Watson, J., An introduction to game theory. W. W. Norton \& Company, New York, 2013.

Received: March 2017, revised: February 2018 